\title{
Environmental Accounting and Reporting: Case Study of Accounting Education in Indonesia's Universities that Includes in Qs World University Rankings
}

\author{
Kenny Ardillah \\ Matana University Tower, Ara Center, Gading Serpong \\ \{kennyardillah121@gmail.com\}
}

\begin{abstract}
Universities have an important role towards students in building professional competence through the fulfillment of periodic updated learning curricula. This study aims to gather information related to the number of universities, the number of relevant courses, the number of undergraduate and graduate programs, the application of courses that join with other sciences, teaching methodologies, publications in the internal journals of tertiary institutions, activities involving college students, organizations or student associations, website availability, publication of sustainability reports, and participation of environmental assessment at universities in Indonesia included in the QS World University Ranking 2019. This research is a qualitative research with a case study approach. The study population is all universities in Indonesia included in the QS World University Ranking 2019. The research results obtained were $44.44 \%$ of the universities included in the QS World Rankings University 2019 rank had integrated courses related to environmental accounting and reporting in the education curriculum at the level proportion of $1.24 \% .33 .33 \%$ of universities apply study programs that are still relevant to the aspects of sustainability and the environment in their educational curriculum. All universities have courses outside the concepts of environmental accounting and reporting that combine with other sciences. All universities apply teaching methods in the classroom. The University has an average of 5 publications per year of research related to environmental accounting and reporting. The university still has a sufficient number of activities of 5-7 activities involving students related to environmental sustainability. $77.78 \%$ of universities already have student-student organizations that help in reducing social and environmental problems. $66.67 \%$ of universities already have websites related to environmental sustainability. Only $33.33 \%$ of universities publish sustainability reports on the university's website. All universities have participated in environmental and sustainability assessment through the 2019 University Indonesia Green Metrics and as many as 6 out of $9(66.67 \%)$ universities has contributed to the achievement of SDGs in the world by getting top 200 in Times Higher Education University Impact Rankings.
\end{abstract}

Keywords: Environmental Accounting and Reporting, Accounting Education, Universities, QS World University Rankings 


\section{Introduction}

The Brundtland Report defines sustainable development as development that meets current needs without reducing the ability of future generations to meet their own needs [69]. Sustainable development is important to ensure that the world will continue to have adequate water, materials and other resources for its living systems. It also means that any sustainable development must involve the right economic balance, social conditions, and the environment [70]. For academic institutions, the 1972 Stockholm Declaration which discussed Sustainability in Higher Education (SHE) became the beginning for all the university community, starting from leaders, lecturers, researchers, and students to be able to use existing resources in responding to the challenges of the balance of economic development and technology with environmental preservation [30].

The Association of Chartered Certified Accountants (ACCA) in collaboration with Accounting for Sustainability in 2014 conducted a study of students' views on sustainability issues. As many as 87 percent of students from 126 countries believe that the accountant profession needs to provide more insight into decisions about sustainability. As many as 79 percent of the students agreed that the issue of sustainability would be very important in the next 10 years. As many as $74 \%$ agree that environmental impact on organizations will be a greater focus for the accounting profession and 54\% want to be involved in integrating sustainability issues into business. This condition should be a trigger for accounting education institutions to increase awareness of the importance of knowledge related to sustainability issues to be given to students in the learning process while they are studying in universities [22].

The University of Western Michigan in 2018 have conducted a Student Sustainability Survey with 1,664 respondents who were college students who had been joined in the universities from the first to fourth academic years. As many as $72 \%$ of respondents know the importance of office for sustainability and 55\% of respondents understand the opportunities that can be obtained from the existence of office for sustainability such as sustainability scholarships and internships at companies that join us sustainability. In addition, as many as $61 \%$ of respondents have implemented efforts that could arise with opportunities from sustainability issues such as ecojug, house potlucks, and bicycle repair shop [71, 72].

QS World University Ranking by Subject annually releases a list of the world's best universities based on the category of discipline or department. British educational research's institute has evaluated 4,500 universities in the world in 48 scientific fields and published the best a thousand universities for the first time in 2019. Universities in the world have become increasingly productive in relation to the publication of research results. The mapping ranking of papers published and indexed by the Scopus Elsevier database from 2012-2016 has increased significantly to be equivalent to nearly 13 million papers and 67 million citations. The best universities in the world have more than 47,000 citations from all publications with an increase of $22.2 \%$ on an annual basis. QS World University Ranking also becomes the ranking system of world universities which is a reference of the Ministry of Research, Technology and Universities in determining the real achievement of universities performance in Indonesia. In 2019, there were nine universities in Indonesia that were included in the QS World University Rankings [32]. In addition to having the best achievement in the QS World University Ranking University of Indonesia, Universitas Indonesia since 2010 has been actively involved in efforts to reduce carbon emissions and help solve the problem of global climate change. One of the major efforts undertaken by the University of Indonesia is to launch Green Metric, which was a rating system for evaluating sustainability information that 
initially assessed 300 universities that were members of the United States Green Report Card [55].

Study related to the application of environmental accounting education and reporting has been conducted by Ara and Harani who used a case study approach at 100 universities from various countries with gathering information sourced from secondary data available on the college website. Study results obtained by information gathering from 100 universities were 42 universities have significantly added Environmental Accounting and Reporting, universities from the US, UK, Australia and New Zealand offer courses in Environmental Accounting Reporting and Sustainability as a 21st century pedagogical requirement, Environmental Accounting and Reporting is integrated with undergraduate and graduate programs such as the MBA (Business Sustainability); MS (Sustainable development); M.Sc. (Nature, Society and the Environment), BS with specializations such as accounting, management, or a combination of both, iniated the course "Understanding Global Accounting Practices through International Study Tours"; "Reimagining Capitalism: Business and Big Issues"; "Sustainability Management of Asset Design for Portfolio Management" demonstrates the development of traditional concepts of environmental accounting and reporting, and teaching methodologies carried out by teaching by experts, seminars, discussions, reading books on related topics, projects and assignments that cover real issues relating to the environment and business [1].

In addition, the first last study states that accounting and finance lags behind management disciplines in instilling sustainability and institutional commitment must be a strong necessity for integrating sustainability effectively [23]. The second last study states the efforts to highlight environmental awareness in developing countries such as India and discuss issues related to the application of environmental accounting. In India, environmental accounting has transcended differences in irregularities and has become an emergent characteristic that must be considered in compiling accounting schemes within the scope of the company [5]. The third last study stated that damage and environmental problems caused by business activities encourage the integration of environmental accounting in management programs which ultimately can benefit the company in the future [24].

Environmental Accounting is not implemented because it is not statutory because eventhought the universities insists on environmental education at the undergraduate courses, but the syllabus of commerce curriculum does not contain Environmental Accounting. It becomes a national and international duty of all enterprises to fulfill the Kyoto Protocol international agreement requirements to protect environment [27].

The motivation for doing this study is that there is still a small amount of study in Indonesia that has a positive impact on the development of higher accounting education in Indonesia related to environmental accounting and reporting and the writer's attention in responding to accounting education to meet the needs of future accountant competencies in the field of social and environmental accounting. This study aims to gather information related to accounting education in Indonesia that is included in the QS World University Rankings at the faculty of economics and business level which has integrated the concepts of environmental accounting and reporting in terms of numbers and proportion of subjects relevant to the total number of subjects taught, number of undergraduate and graduate programs that have integrated the concepts of environmental accounting and reporting, number and proportion of courses outside the traditional concepts of social and environmental accounting that join with other fields of study, related learning methods teaching subjects. In addition, this study adds other accounting education indicators taken from the measurement component of the UI GreenMetric, namely the average number of scientific publications published about 
environmental sustainability each year in internal journals of higher education, higher education activities involving students related to sustainability, student organizations related environment, sustainability sites, publication of sustainability reports, and participation in environmental assessment.

\section{Theoretical Framework and Hyphotesis Development}

\subsection{Stakeholder Theory}

The stakeholder theory assumes that stakeholder support supports the existence of a company, so that company activities must consider the approval of stakeholders in carrying out its operations activities [19]. When connected with stakeholders in the context of universitiess, the public and the private sector are the target groups of higher education outputs who are customers of universities [20]. Good educators are required to help students in obtaining the skills needed to be involved in resolving ongoing issues in society. This has encouraged many business schools to prioritize meeting the needs of their main stakeholders who in addition to meeting the business needs of trained human resources but must also be members of the community responsible for external conditions, especially related to sustainability aspects $[2,3,73]$.

\subsection{Social and Environmental Accounting}

Social and environmental accounting is often referred as green accounting, environmental accounting, or sustainability accounting. Social and environmental accounting is defined as an accounting system designed to promote sustainability strategies and extension or modification to financial accounting, cost accounting, or management accounting [26]. In terms of implementation, social and environmental accounting depends on the characteristics of the company in understanding environmental issues that lead the company to carry out policies related to the environment. The purpose of environmental and social accounting is to provide relevant environmental and social cost information to parties who need it, as well as a means of communication between companies and the community [29].

\subsection{Accounting, Sustainability Reporting and University Contribution}

The role of accounting is becoming increasingly important at this time with the increasing need for information and the emergence of unresolved social and environmental problems. The pressure to integrate the issue of sustainability into the company's decision-making system ultimately directs business people to carry out operations that support sustainable development [4]. Sustainability reporting has become a necessity to support business decision making by both company management and stakeholders. Because of the existence of the sustainability report, the company's sustainability practices can be traced [22]. Universities as well as the companies face new and complex demands. Educators in the field of social science play a key role in raising awareness among students of the importance of corporate social and environmental responsibility, for example in lectures lecturers can emphasize that accountants have a role in preparing sustainability reporting so students are expected to be better prepared to manage social problems and the environment that the company faces [28]. 


\subsection{Green Campus Initiation}

Green campus is a campus that functions according to a cultural system that supports the preservation of a broad environment and balances design with available resources. Green campus is a place of practice that requires responsibility for the environment in line with education in which the principles of being responsible for the environment are realized. As an institution of higher education, the concept of a green campus can offer opportunities to lead in rethinking environmental culture and developing new paradigms to solve local, national, and global problems. The drive for a successful Green campus must start from top management and come from all the community members at the college. Without strong commitment and good involvement from top management, this well-intentioned initiative can be an obstacle to increasing broad participation to implement this green campus across colleges [25].

\subsection{QS World University Ranking}

QS World University Ranking annually releases a list of the best universities in the world based on the category of discipline or department. To do the rank, the British educational research institute has evaluated 4,500 universitiess in the world in 48 scientific fields and published 1,000 of the best universitiess. QS World University Rankings are prepared using simple indicators that summarize university performance at a global level that adjusts with key aspects of the vision and mission of higher education. The stability in the rank methodology for measuring this indicator every year ensures that year-to-year comparisons remain valid and volatility in the indicators can be minimized. Universities' evaluation for the QS World University Rankings are compiled based on six indicators designed to determine research efficiency, academic standing, fostering graduate work skills, class sizes, and the extent to which internationalization is being achieved as follows [32].

a. Academic Reputation (40\%)

b. Employer Reputation $(10 \%)$

c. Faculty / Student Ratio $(20 \%)$

d. Quotations per faculty $(20 \%)$

e. International Faculty Ratio (5\%)

f. International Student Ratio (5\%)

\subsection{UI GreenMetric}

Universitas Indonesia's GreenMetric is a measurement instrument made by the Universitas Indonesia in measuring sustainability efforts undertaken by universitiess. GreenMetric is not based on a single ranking system, but was developed with the awareness of a number of existing sustainability assessment systems with reference to university academics. The GreenMetric sustainability system was developed by combining measurement indicators from The Holcim Sustainability Awards, GREENSHIP which is a ranking system recently developed by the Green Building Concil of Indonesia based on Leadership in Energy and Environmental Design (LEED) used in the United States and countries others, Sustainability, Tracking, Assessment and Rating System (STARS), and The College Sustainability Report Card (also known as the Green Report Card). In general, GreenMetric instruments adopt the concept of environmental sustainability which has three elements, namely environmental, economic, and social [55]. 


\subsection{Times Higher Education University Impact Rankings}

The University Impact Rankings measure global universities' success in delivering the UN Sustainable Development Goals. Times Higher Education University Impact Rankings are the only global performance tables that assess universities against the United Nations' Sustainable Development Goals (SDGs). The ranking uses indicators to provide comprehensive and balanced comparisons across three broad areas contain research, outreach, and stewardship aspect. There are 17 UN SDGs to evaluate universities performance, but only 11 of them are evaluated to be ranked as follows [31].

a. SDG 3 - Good health and well-being

b. SDG 4 - Quality education

c. SDG 5 - Gender equality

d. SDG 8 - Decent work and economic growth

e. SDG 9 - Industry, innovation, and infrastructure

f. SDG 10 - Reduced inequalities

g. SDG 11 - Sustainable cities and communities

h. SDG 12 - Responsible consumption and production

i. SDG 13 - Climate action

j. SDG 16 - Peace, justice and strong institutions

k. SDG 17 - Partnerships for the goals

\section{Research Method}

The object of research in this study is the number of universitiess, the application of relevant subjects, relevant undergraduate and graduate programs, the application of courses outside the traditional social and environmental accounting concepts that join with other sciences, learning methods, research publications in the internal journals of universitiess, college activities involving students, student organizations related to the environment, sustainability sites, publication of sustainability reports, and participation in environmental assessment. The subject of this study is universities in Indonesia. The population of this study are all universities in Indonesia that are included in the QS World University Rankings 2019. There are 9 universities in Indonesia that are included in the QS World University Rankings 2019, namely the Universitas Indonesia which ranked $296^{\text {th }}$, Universitas Gajah Mada which ranked $320^{\text {th }}$, Institut Teknologi Bandung which ranked $331^{\text {th }}$, Institut Pertanian Bogor which ranked $601-650^{\text {th }}$, Universitas Airlangga which ranked $651-700^{\text {th }}$, Padjadjaran University which ranked $751-800^{\text {th }}$, Diponegoro University which ranked $801-1000^{\text {th }}$, Sepuluh November Institute of Technology which ranked $801-1000^{\text {th }}$, and Brawijaya University which ranked $801-1000^{\text {th }}$ [32]. This study is qualitative type with a case study approach to explain the application of accounting education that integrates the concepts of environmental accounting and reporting in all universities in Indonesia which are included in the QS World University Rankings 2019. The method of data collection in this study is literature study by finding theories that are relevant and collecting the necessary data that comes from media that has a relationship with the same problem in research discussions and various sources of data publication such as university websites and other sources of external publications that are reviewed for gathering information that supports the purpose of this study. 


\section{Results}

\subsection{Universitas Indonesia}

Universitas Indonesia's Faculty of Economic and Business was established on September 18, 1950 which makes Universitas Indonesia's Faculty of Economic and Business as one of the oldest faculties of economics and business in Indonesia. Faculty of Economic and Business in Universitas Indonesia is located on two campuses namely the Widjojo Nitisastro's Depok Campus and the Sumitro Djojohadikusumo's Salemba Campus. Faculty of Economic and Business in Universitas Indonesia has three main courses, namely Bachelor, Master, and Doctor degree. There are three Universitas Indonesia's Faculty of Economic and Business departments namely Department of Economics, Department of Management, and Department of Accounting. Department of Economics oversees Bachelor of Economics, Master of Economics and Doctor of Economics, Master of Planning and Public Policy, and Masters of Economic Planning and Development Policy. The Department of Management is in charge of Bachelor of Management, Undergraduate Extension Bachelor of Management, Master of Management Sciences and Doctor of Management Sciences, and Masters of Management. The Department of Accounting is in charge of Bachelor of Accounting's (Regular, Parallel and Extension), Master of Accounting, and Doctor of Accounting [64, 66].

Faculty of Economic and Business in Universitas Indonesia has integrated environmental accounting and reporting in the education curriculum in Bachelor of Accounting. Faculty of Economic and Business in Universitas Indonesia has one elective subject related to environmental accounting and reporting in Regular and Parallel Bachelor of Accounting, namely Sustainability Reports and Environmental Audit with a proportion of $1.37 \%$ and one regular course in Doctor of Accounting Science, namely Governance and Sustainability Doctoral Seminar with a proportion of 5.26\%. The application of the Sustainability Report and Environmental Audit's courses is intended to provide students with knowledge related to sustainability and their implications for companies. This course is also intended to provide sustainability management practices related to accountability and disclosure of social and environmental performance and the application of international standards and procedures for preparing sustainability reports and assurance on sustainability reports. Governance and Sustainability Doctoral Seminar's course are aimed at developing new knowledge or contributing to increasing the mastery of accountant professionalism based on new knowledge related to governance and sustainability $[56,57,62,64]$.

Faculty of Economic and Business in Universitas Indonesia has a graduate program that is still relevant to environmental sustainability, namely Master of Economics with the concentration of Economics, Environmental, and Natural Resources. Faculty of Economic and Business in Universitas Indonesia has one elective subject in the Masters of Economics related to subjects outside the concepts of environmental accounting and reporting, namely Environmental Economics and Natural Resources with a proportion of $3.44 \%$ and two regular courses at the Masters in Economic Planning and Development Policy, namely Economics and Energy Policy and Natural Resources and Environmental Policy with a proportion of $10 \%$ [61, 63]. Faculty of Economic and Business in Universitas Indonesia has an average of one scientific publication per year which integrates the concepts of environmental accounting and reporting in the South East Asian Management Journal (SEAM) [60]. Faculty of Economic and Business in Universitas Indonesia describes methods of teaching and learning in class combined with case work, class discussion, in-class experiential exercise, independent research, comparative learning, and sharing experiences with experts for courses related to environmental 
accounting and reporting $[61,62,63,64,66]$.

Annually, Universitas Indonesia has more than ten activities per year which involve students related to environmental sustainability with the main program namely UI Go Green and other programs covering community empowerment, campus love programs, conference, seminar, and workshops related to environment. Universitas Indonesia has five student organizations related to sustainability, namely Green Community of the University of Indonesia, MAPALA Universitas Indonesia, Community Development Center, ILUNI, and Alumni Care Center. Universitas Indonesia has three websites that discuss environmental sustainability with website address https://greenmetric.ui.ac.id and http://green.ui.ac.id/ as well as websites that support the implementation of SDGs namely http://www.sci.ui.ac.id/ [58, 59, 65]. Universitas Indonesia has published the 2018 Green Metric Report and Universitas Indonesia's Faculty of Medicine publishes the 2018 Green Campus Report on the website http://green.ui.ac.id/ [58]. Universitas Indonesia participated in the 2019 Green Metric assessment and won the best award as the 2019 Greenest Campus in Indonesia with UI Green Metric version and ranked 40th in the world in the category of environmentally friendly campus [55]. Universitas Indonesia participated in the World University Impact Rankings 2020 assessment and ranked 80th in the world by achieving 3 SDGs namely SDGs 3 Healthy and Prosperous Life, SDGs 4 Quality Education, and SDGs 17 Partnerships for Achieving Goals [21].

\subsection{Universitas Gajah Mada}

In 1952, education and economic's lectures in Universitas Gajah Mada (UGM), was carried out by the Department of Economics which was coordinated by the Law Department namely Faculty of Law, Economics, Social and Politics (Faculty of HESP). Starting from the academic year 1955/1956, the Faculty of HESP was divided into three faculties namely the Faculty of Law, the Faculty of Economics, and the Faculty of Social Politics. The UGM Faculty of Economics, which changed its name to FEB in 2007 is the third state faculty of economics in Indonesia. The name of the Universitas Gajah Mada's Faculty of Economics changed to Universitas Gajah Mada's Faculty of Economics and Business to meet the gointernational goals that make it easier for Universitas Gajah Mada's Faculty of Economics and Business to adapt in the international community. The Faculty of Economics and Business in Universitas Gajah Mada has three departments namely accounting, economics and management departments. The accounting department of Universitas Gajah Mada's Faculty of Economics and Business has Bachelor of Accounting, Master of Accounting, and Doctor of accounting study programs. The Management Department in Universitas Gajah Mada's Faculty of Economics and Business has Bachelor of Management, Master of Management, Master of Management, and Doctor of Management Sciences. The Department of Economics in Universitas Gajah Mada's Faculty of Economics and Business has Bachelor of Economics, Master of Economics, Master of Economic Development, and Doctor of Economics [50].

The Faculty of Economics and Business in Universitas Gajah Mada has not yet integrated environmental accounting and reporting in the education curriculum at the undergraduate and graduate degree. The Faculty of Economics and Business in Universitas Gajah Mada has a study program that is not relevant to environmental sustainability, but has several subjects related to environment and sustainability, namely Master of Development Economics. The Faculty of Economics and Business in Universitas Gajah Mada has two courses related to subjects outside the concepts of environmental accounting and reporting, namely Natural and Environmental Resources Economics and Community Empowerment Strategies with a 
proportion of $5.12 \%$ in Masters of Development Economics with the concentration of AgroMaritime Rural Economics [53]. The Faculty of Economics and Business in Universitas Gajah Mada has an average of one scientific publication each year which integrates the concepts of environmental accounting and reporting in the Universitas Gajah Mada's Journal of Indonesia Economy and Business [52]. The Faculty of Economics and Business in Universitas Gajah Mada uses classroom lecturing methods through interactive discussions, assignment of case studies with current issues, and field studies for courses related to environmental accounting and reporting $[50,53]$.

Universitas Gajah Mada has more than ten activities that involve students each year related to environmental sustainability such as international conferences and seminars related to the environment, social contribution projects, social entrepreneurship, street socialization, and Go Green's campaign. Universitas Gajah Mada has a student organization related to sustainability, namely the Environmental Geography Student Association [50, 53, 54]. Universitas Gajah Mada has a website related to sustainability with address http://insgreeb.ft.ugm.ac.id/smartand-green-campus/as UGM's commitment to become The Green Leading Campus. Universitas Gajah Mada currently does not have a publication on environmental sustainability reports [51]. Universitas Gajah Mada participated in 2019 Universitas Indonesia's Green Metric as an assessment program organized by the Universitas Indonesia and was ranked third nationally [55]. Universitas Gajah Mada participated in the 2019 Times Higher Education University Impact Rankings and won the 101-200 world ranking with the top 50 ranking in SDGs 8 Decent Work and Economic Growth contributions and the top 70 ranking in the SDGs 5 Gender Equality contribution [21].

\subsection{Institut Teknologi Bandung}

Business and management education in Indonesia were initiated by the Institut Teknologi Bandung's Industrial Engineering Department in the early 1970s, but the idea could not yet be realized until finally in the beginning of 1990s when Prof. Mathias A'roef who is a prominent figure in Indonesia in the field of Industrial Engineering introduced an MBA program at Institut Teknologi Bandung with a concentration in operational management that culminated in the establishment of the Institut Teknologi Bandung's School of Business and Management with the main study programs namely Bachelor of Management, Bachelor of Leadership, Masters of Business Administration, Masters of Management Science, and Doctor of Management Science [16].

Institut Teknologi Bandung has not yet integrated environmental accounting and reporting in the educational curriculum at Institut Teknologi Bandung's School of Business and Management. School of Business and Management in Institut Teknologi Bandung has a study program that is not relevant to environmental sustainability but applies several courses related to sustainability, namely the Master of Development Studies. School of Business and Management in Institut Teknologi Bandung has four courses outside the concepts of environmental accounting and reporting, namely Project Management for Sustainable Development, Environmental Governance, Sustainable Development, and Sustainable Development Economics in Master of Development Studies with a proportion of 18.18\%. School of Business and Management in Institut Teknologi Bandung does not have research publications that integrate the concepts of environmental accounting and reporting in Institut Teknologi Bandung's School of Business and Management online journals [16].

School of Business and Management in Institut Teknologi Bandung monitors and evaluates students with classroom learning methods through student presentations and lectures or field 
studies for related subjects outside the concepts of environmental accounting and reporting. School of Business and Management in Institut Teknologi Bandung does not have any scientific publications each year which integrates the concepts of environmental accounting and reporting. Institut Teknologi Bandung has more than five activities involving students per year related to environmental sustainability such as the Reduce, Separate and Utilize Movement, public lectures, and seminars related to the environment. Institut Teknologi Bandung does not have a student organization related to sustainability $[15,16]$. Institut Teknologi Bandung has a website that addresses sustainability with website address www.ecocampus.itb.ac.id [14]. Institut Teknologi Bandung currently has no publication of environmental sustainability reports. Institut Teknologi Bandung participated in the 2019 Universitas Indonesia's Green Metric as an assessment program organized by the University of Indonesia and was ranked twenty-first nationally [55]. Institut Teknologi Bandung entered the Times Higher Education University Impact Rankings 2019 rating list and achieved 301+ rankings with the acquisition of SDGs 4 Quality Education, SDGs 5 for Gender Equality, SDGs 9 Industry, Innovation, and Infrastructure, and SDGs 17 Partnerships for Achieving Goals [21].

\subsection{Institut Pertanian Bogor}

The establishment of the Faculty of Economics and Management was written on a plaque signed by Indonesian Vice-President Megawati Soekarnoputri on April 6, 2001. When it was first established, Faculty of Economics and Management in Institut Pertanian Bogor only had two study programs namely the Economic Study Program and the Management Study Program. The two programs were subsequently declared as departments in 2007 and afterwards restructuring was carried out on Faculty of Economics and Management by forming two new departments namely the Agribusiness Department and the Resource and Environmental Economics Program. Faculty of Economics and Management in Institut Pertanian Bogor has had four majors and one study program, namely Bachelor and Masters of Economics and Development Studies, Bachelor and Master of Management, Bachelor and Master of Agribusiness, Bachelor of Resource and Environmental Economics and Master of Agricultural Economics, Bachelor, Master, and Doctor of Environmental Economics and Natural Resources, Master and Doctor of Economics of Tropical Maritime Resources, and Bachelor of Sharia Economics $[8,13]$.

Faculty of Economics and Management in Institut Pertanian Bogor has not yet integrated environmental accounting and reporting in its educational curriculum. Faculty of Economics and Management in Institut Pertanian Bogor has seven study programs which were still relevant to environmental sustainability, namely Bachelor of Economics with the concentration of Resources and Environment, Bachelor of Environmental Economics and Natural Resources, Master of Environmental Economics and Natural Resources, and Doctor of Environmental Economics and Natural Resources, Master of Tropical Marine Resources Economics, Doctor of Tropical Marine Resources Economics, and Doctor of Agricultural Economics specializing in Resource and Environmental Economics [6, 7, 8].

Faculty of Economics and Management in Institut Pertanian Bogor has two courses that are still relevant in terms of environmental sustainability beyond the concepts of environmental accounting and reporting which are joined by other sciences in the Bachelor of Economics namely Competitiveness of Sustainable Business and Sustainable Business and Industry with a proportion of $3.33 \%$, nine courses in the Bachelor of Resource and Environmental Economics namely Environmental Economics, Resource Economics, Land Resource Economics, Water Resource Economics, Economic Valuation and Environmental Resources, Political Economics 
of Natural and Environmental Resources, Modeling of Resource and Environmental Economics, Resource Planning and Policy, Economic Assessment of Damage to Resources and The Environment with a proportion of $17,31 \%$, six courses in Master of Resource and Environmental Economics namely Natural Resource Economics, Research Methods for Marine Resource Economics, Marine Resources and National Economic Development, Characteristics of Tropical Marine Resource Management, Economic Valuation, Resources, and Environment, and Marine Resource Economics with a proportion of 33,33 \%, and eighteen courses in Doctor of Resource and Environmental Economics with a proportion of 54,54\% [7, 12].

Masters of Tropical Marine Resources Economics has five relevant subjects related to environmental sustainability beyond the concept of environmental accounting and reporting that joins other sciences, namely Natural Resource Economics, Tropical Marine Resource Economic Research Methodology, Marine Resource Economics and National Development, Characteristics and Management of Tropical Marine Resources, and Behavioral Economics for Natural Resources and the Environment with a proportion of $22.72 \%$. The Doctor of Tropical Marine Resource Economics has four relevant subjects related to environmental sustainability beyond the concept of environmental accounting and reporting that joins other sciences, namely Advanced Natural Resource Economics, Advanced Marine Resource Economics, Dynamic Economic Models for Natural Resources and the Environment, and Economic Policy in Management of Sustainable Marine Development with a proportion of $15.38 \%$. The Masters in Regional Development Management has two courses that are still relevant in terms of environmental sustainability beyond the concepts of environmental accounting and reporting that are joined by other sciences, namely Natural Resource Management and Environment and Innovation and Sustainability with a proportion of $6.25 \%$. The Doctor of Agricultural Economics Specialization in Resource Economics and the Environment has two courses that are still relevant in terms of environmental sustainability beyond the concept of environmental accounting and reporting that joins other sciences, namely Advanced Natural Resource Economics and Economics and Advanced Environmental Policy with a proportion of 5.55\% [8, 12].

Faculty of Economics and Management in Institut Pertanian Bogor has an average of one research publications per year that integrate the concept of environmental sustainability in the Journal of Natural Resources and Environmental Management [11]. Faculty of Economics and Management in Institut Pertanian Bogor explained the teaching learning method through lectures and class discussions for related subjects outside the concepts of environmental accounting and traditional reporting. Institut Pertanian Bogor has up to ten activities involving students related to environmental sustainability with Institut Pertanian Bogor's main program towards Green Campus 2020 and other programs such as zero waste campaigns, activities to become Heroes of the Environment, seminars, and business initiation activities related to the environment. Institut Pertanian Bogor has four student organizations related to sustainability namely Environmental SMEs consisting of the Indonesian Green Action Forum (IGAF) and Agricultural Student Green Movement (Agreemove) and Nature Lovers SMEs consisting of Lawalata and Fauna Conservation Units [6, 7, 8, 10, 12, 13].

Institut Pertanian Bogor has a website that addresses environmental sustainability namely http://greencampus.ipb.ac.id/. Institut Pertanian Bogor has published a report on environmental sustainability through the Green Campus Booklet entitled Towards Green Campus 2020 [9]. Institut Pertanian Bogor participated in the 2019 Universitas Indonesia's Green Metric as an assessment program organized by the Universitas Indonesia and was ranked second nationally and ranked 40th of the best green campus in the world [55]. Institut Pertanian Bogor is also recognized as a university with the world's top 100 Times Higher Education University Impact 
Rankings 2019 with contributions to the achievement of SDGs 9 indicators for Industrial, Innovation and Infrastructure, SDGs 12 Responsible Consumption and Production, and SDGs 13 Handling Climate Change. IPB also ranks 101-200 Times Higher Education University Impact Rankings 2019 for two other SDGs indicators namely SDGs 5 Gender Equality and SDGs 11 Cities and Sustainable Settlements which rank IPB as the first rank in Indonesia to achieve this SDGs indicator [21].

\subsection{Universitas Airlangga}

Universitas Airlangga as one of oldest public university in Surabaya, which operated in the beginning in 1952 and established under the name Krisnadwipayana College of Economics, which was founded by Dr. Ong Eng Djie who was the Minister of Finance of the Republic of Indonesia that year. Because of several things one year later, the college broke up and became active again in 1954 under the name of the Surabaya Economic College. In 1961, Surabaya Economic College changed its name to Faculty of Economics, Universitas Airlangga. Subsequently in 2010, the Faculty of Economics in Universitas Airlangga changed its name to the Faculty of Economics and Business [34].

The Faculty of Economics and Business in Universitas Airlangga currently has three main courses, namely the Bachelor, Magister, and Doctoral Program. There are 4 departments at The Faculty of Economics and Business in Universitas Airlangga namely Accounting's Department, Management's Department, Economics' Department, and Islamic Economics Department. Department of Accounting in Universitas Airlangga consists of four study programs namely Bachelor of Accounting, Masters of Accounting, Doctor of Accounting, and Professional Accounting Education. The Management Department in Airlangga Universitas Airlangga consists of four study programs, namely Bachelor of Management, Master of Management, Master of Management Science, and Doctor of Management Science. The Department of Economics in Universitas Airlangga consists of three study programs namely Bachelor of Development Economics, Masters of Economics, and Doctor of Economics. Department of Islamic Economics in Universitas Airlangga consists of Bachelor and Masters of Islamic Economics [33, 34].

The Faculty of Economics and Business in Universitas Airlangga has not integrated environmental accounting and reporting due to the absence of relevant subjects related to environmental accounting and reporting. The Faculty of Economics and Business in Universitas Airlangga has a study program that is not relevant to environmental sustainability, but has courses related to the environment namely the Bachelor of Development Economics. The Faculty of Economics and Business in Universitas Airlangga has one course outside the concepts of environmental accounting and reporting that joins other sciences, namely Natural Resource Economics and Environment in Bachelor of Development Economics with a proportion of $1.49 \%$, one course in Masters of Economics, namely Business Ethics and Corporate Social Responsibility with proportion of $4.17 \%$, and two courses in the Doctor of Economics, namely Sustainable Development Economics and Environmental Economics with a proportion of $11.76 \%[33,34]$. The Faculty of Economics and Business in Universitas Airlangga has an average of one scientific publication annually related to sustainability in the Journal of Developing Economics [35]. The Faculty of Economics and Business in Universitas Airlangga explained the teaching and learning methods through classroom lectures, discussions and questions and answers, tutorials, and presentations for courses related to environmental accounting and reporting [33, 34, 36].

Universitas Airlangga has more than five activities each year that involve students related 
to environmental sustainability through the Real Work Lecture program, community service programs, online discussion, and international conferences related to economics and the environment. Universitas Airlangga does not have student organizations related to sustainability. Universitas Airlangga does not have a website that addresses environmental sustainability. Universitas Airlangga does not have a sustainability report publication on the college website [33, 34, 36]. Universitas Airlangga participated in the 2019 Universitas Indonesia's Green Metric as an assessment program which organized by the Universitas Indonesia and was ranked fifteen nationally [55].

\subsection{Universitas Padjajaran}

The Faculty of Economics and Business in Universitas Padjajaran was established based on Government Regulation Number 37 dated September 18, 1957 which concern the establishment of Unpad on September 11, 1957. The Faculty of Economics and Business in Universitas Padjajaran was under the auspices of the Merdeka University's Bandung Foundation which was founded in 1952 under the name of Universitas Merdeka which in its development became Universitas Padjadjaran in 1957. The Faculty of Economics and Business in Universitas Padjajaran until now has a bachelor program consisting of Bachelor of Accounting, Bachelor of Management, Bachelor of Development Economics, Bachelor of Islamic Economics, and Bachelor of Digital Business. The Faculty of Economics and Business in Universitas Padjajaran has postgraduate programs in Master of Accounting, Master of Management Master of Economics, Masters of Applied Economics, Master of Integrated Micro Financial Management, and Doctor of Economics [67].

The Faculty of Economics and Business in Universitas Padjajaran has integrated environmental accounting and reporting in the education curriculum in undergraduate accounting study program. The Faculty of Economics and Business in Universitas Padjajaran has a subject related to environmental accounting and reporting, namely Social Accounting in Bachelor of Accounting with a proportion of 2.08\%. The application of Social Accounting's courses aims to provide knowledge about the concepts of social accounting. The Faculty of Economics and Business in Universitas Padjajaran has a study program that is not relevant to environmental sustainability, but has a course related to the environment, namely the Bachelor of Development Economics. The Faculty of Economics and Business in Universitas Padjajaran has two courses related to subjects outside the concepts of environmental accounting and reporting with one course in the Bachelor of Accounting, namely Oil and Gas Accounting with a proportion of $2.08 \%$ and one course in Masters of Development Economics, namely Natural Resource Economics and The Environment with a proportion of $1.72 \%$. The Faculty of Economics and Business in Universitas Padjajaran does not have scientific publications that integrate the concepts of environmental accounting and reporting. The Faculty of Economics and Business in Universitas Padjajaran uses classroom teaching methods in the form of lectures and class discussions, cooperative and problem-based learning, and learning with reporting methods for related subjects outside the concepts of environmental accounting and traditional reporting $[67,68]$.

Universitas Padjajaran has more than five activities involving students per year related to environmental sustainability such as business forums, workshops, and seminars related to the environment. Universitas Padjajaran does not have a website that promotes environmental sustainability. Universitas Padjajaran has a student organization that is still relevant to environmental sustainability namely PALAWA (Nature Lover Student's Association) Universitas Padjajaran. Universitas Padjajaran has no publication of environmental 
sustainability's report [68]. Universitas Padjajaran participated in the 2019 Universitas Indonesia's Green Metric as assessment program which organized by the Universitas Indonesia and was ranked 10th nationally. Universitas Padjajaran participated in the 2019 Universitas Indonesia's Green Metric as an assessment program organized by the University of Indonesia and was ranked 10th nationally [55]. Padjadjaran University was awarded 301+ Times Higher Education University Impact Rankings 2019 with the success of IPB in achieving indicators SDGs 8 Decent Work and Economic Growth, SDGs 9 Industry, Innovation, and Infrastructure, and SDGs 16 Peace, Justice and Resilient Institutions [21].

\subsection{Universitas Diponegoro}

Universitas Diponegoro's Faculty of Economics was established on March 14, 1960 as one of the oldest economics faculties in Semarang. In 2011, The Faculty of Economics in Universitas Diponegoro changed its name to Universitas Diponegoro's Faculty of Economics and Business. The Faculty of Economics and Business in Universitas Diponegoro has three departments and one study Program namely the Department of Management, Department of Economics and Development Studies, Department of Accounting, and Islamic Economics' Study Programs. Universitas Diponegoro's Management Department consists of Bachelor of Management and Masters of Management. The Department of Economics in Universitas Diponegoro's Faculty of Economics and Business consists of Bachelor of Economics and Development Studies, Masters of Economics and Development Studies, and Doctor of Economics. The Department of Accounting in Universitas Diponegoro's Faculty of Economics and Business consists of Bachelor of Accounting, Masters of Accounting, and the Accounting Professional Program [48].

The Faculty of Economics and Business in Universitas Diponegoro has not yet integrated environmental accounting and reporting in the education curriculum in undergraduate and graduate programs in accounting and economics and development studies. The Faculty of Economics and Business in Universitas Diponegoro has a study program that is still relevant to environmental sustainability, namely Bachelor of Economics and Development Studies with a concentration of Resource Economics. The Faculty of Economics and Business in Universitas Diponegoro has three courses outside the concepts of environmental accounting and reporting in economics in the Bachelor of Economics and Development Studies in the concentration of Resource Economics namely Natural Resource Economics and Environment I, Natural Resource Economics and Environment II, and Resources Economic Seminars with the proportion of $4.22 \%$. The Faculty of Economics and Business in Universitas Diponegoro has an average of more than ten scientific publications per year that integrate the concepts of environmental accounting and reporting in the Diponegoro Journal of Accounting annually. The Faculty of Economics and Business in Universitas Diponegoro monitors and evaluates students related to subjects related to environmental accounting and reporting with lecture, presentation, and discussion learning methods [47, 48].

Universitas Diponegoro has more than five activities involving students per year related to environmental sustainability such as Real Work Lecture, Caring for Nation, Garbage Reduction's Campaign, Nature's Love Action, and Healthy Walk. Universitas Diponegoro does not have a website that promotes environmental sustainability. Universitas Diponegoro has a student organization that is still relevant to environmental sustainability, namely PALAWA Undip Nature Lover Student's Association. Universitas Diponegoro currently does not have a publication on environmental sustainability reports [47, 48, 49]. Universitas Diponegoro participated in the 2019 Universitas Indonesia's Green Metric as assessment program organized 
by the Universitas Indonesia and was ranked fourth nationally [55]. Universitas Diponegoro participated in the Times Higher Education University Impact Rankings 2019 assessment program and ranked 101-200 in the world with contributions to the achievement of SDGs 3 indicators Health and Welfare, SDGs 12 Responsible Consumption and Production, SDGs 13 Handling Climate Change, and SDGs 17 Partnerships in Achieving Goals [21].

\subsection{Institut Teknologi Sepuluh Nopember}

Institut Teknologi Sepuluh Nopember as a technology and science-based university undertook the development of "social engineering" with a multi-disciplinary approach through the Bachelor in Development Study Program on January 18, 2019. The development of this study program is expected to produce a more comprehensive intellectual output as a form of elaboration and orientation on how development should be managed in order to produce the welfare needed by many people. Institut Teknologi Sepuluh Nopember Development Study's Undergraduate Program is the driving force, creativity and innovation that places science and technology in accordance with humanitarian interests and meets the needs for sustainable development [17].

Institut Teknologi Sepuluh Nopember has integrated environmental accounting and reporting in the education curriculum in the development studies undergraduate program. Institut Teknologi Sepuluh Nopember has courses that are relevant to environmental accounting and reporting in undergraduate programs in economics and development studies, namely Corporate Social Responsibility with a proportion of $2.08 \%$. Institut Teknologi Sepuluh Nopember has a study program that is not relevant to environmental sustainability but has several courses related to environmental sustainability, namely Bachelor of Development Studies. Institut Teknologi Sepuluh Nopember has three courses outside the concepts of environmental accounting and reporting, namely Feasibility Study and Environmental Impacts, Sustainable Development, and Sustainable Communities: Theory and Practice in Bachelor of Development Studies programs with a proportion of $6.25 \%$. Institut Teknologi Sepuluh Nopember does not has scientific publications that integrate the concepts of environmental accounting and reporting in the internal journals of universitiess. Institut Teknologi Sepuluh Nopember monitors and evaluates students regarding subjects related to environmental accounting and reporting through classroom teaching, case studies of important and contextual issues, and the application of mentors from lecturers invited to courses related to environmental accounting and reporting [17].

Institut Teknologi Sepuluh Nopember has more than five activities involving students per year related to environmental sustainability with the main program namely Institut Teknologi Sepuluh Nopember Smart Eco Campus and other programs such as responsive and environmental care actions, seminars, guest lecturer series, and international conferences related to the environment. Institut Teknologi Sepuluh Nopember has a website that discusses environmental sustainability, namely Institut Teknologi Sepuluh Nopember's Eco Campus with website address $h t t p: / / w w w . i t s . a c . i d / i n i a t i v e s / s m a r t-e c o-c a m p u s /[18]$. Institut Teknologi Sepuluh Nopember has a student organization namely SIKLUS that love the environment and maintain harmonious and balanced environmental conditions in a sustainable manner. Institut Teknologi Sepuluh Nopember publishes Institut Teknologi Sepuluh Nopember Point - Institut Teknologi Sepuluh Nopember Smart Eco Campus's environmental sustainability report. Institut Teknologi Sepuluh Nopember participated in the 2019 Universitas Indonesia's Green Metric as an assessment program organized by the Universitas Indonesia and was ranked fifth nationally [55]. 


\subsection{Universitas Brawijaya}

Universitas Brawijaya's Faculty of Economics and Business was established on June 27, 1957 under the name PTEM. The name of Brawijaya was given specifically by President Soekarno in the hope of being able to resound as Raden Wijaya (Brawijaya I) as the founder of the Majapahit Kingdom and at the same time became the proud campus of the Indonesian nation. As one of the oldest universities in Indonesia, The Faculty of Economics and Business in Universitas Brawijaya has a vision to become an international standard educational institution in the fields of economics and business with an entrepreneurial spirit and awareness of divinity, humanity, and the environment. The Faculty of Economics and Business in Universitas Brawijaya has five Study Programs at the undergraduate level namely Bachelor of Accounting, Bachelor of Development Economics, Bachelor of Management, Bachelor of Islamic Economics, Bachelor of Entrepreneurship, and Bachelor of Economics, Finance, and Banking. At the postgraduate level, The Faculty of Economics and Business in Universitas Brawijaya has a study program of Masters of Economics, Masters of Management, Masters of Accounting, Doctor of Economics, Doctor of Management, Doctor of Accounting, and Doctor of Management Science [39].

The Faculty of Economics and Business in Universitas Brawijaya already had courses related to environmental accounting and reporting on the education curriculum at the Bachelor of Accounting, Masters of Accounting, and Doctor of Accounting. The Faculty of Economics and Business in Universitas Brawijaya has a subject related to environmental accounting and reporting in the Bachelor of Accounting with Social Responsibility Accounting's subject with a proportion of $1.28 \%$, a subject in Master of Accounting with Integrated Sustainability and Reporting's subject with a proportion of $2.85 \%$, and a subject in Doctor of Accounting with Sustainability Accounting Research and Corporate Social Responsibility Research's subject with a proportion of $6.67 \%$. The application of integrated sustainability and reporting courses is intended so that students are able to make accounting research within a framework of sustainable research that uses interdisciplinary, multidisciplinary, transdisciplinary and or multi-paradigm approaches that are beneficial to stakeholders and the development of accounting science, producing graduates who have social responsibility, and can develop theories that underlie the role of accounting in reporting and take into account social and environmental aspects. The application of sustainability accounting and Corporate Social Responsibility research courses is intended to make students raise awareness to take responsibility in the social and environmental fields through research in a multi-paradigm perspective that can be beneficial to stakeholders. The Faculty of Economics and Business in Universitas Brawijaya has a study program that is not relevant to environmentally sustainable but has several courses that apply aspects of sustainability, namely Bachelor of Development Economics and Master of Economics with a concentration of development planning and regional finance $[39,41,44]$.

The Faculty of Economics and Business in Universitas Brawijaya has three courses outside the concepts of environmental accounting and traditional reporting in Bachelor of Development Economics with a concentration of resources namely Environmental Economics, Natural Resources Economics, and Natural Resources Economics and Environment Seminars with a proportion of $5.08 \%$ and one course in the Master of Economics namely Resource and Environmental Economics with a proportion of 2.63\% [41, 44]. The Faculty of Economics and Business in Universitas Brawijaya has more than five research publications per year that integrated the concepts of environmental accounting and reporting in the Journal of Multiparadigm Accounting (JAMAL) and The International Journal of Accounting and 
Business Society [42, 43]. The Faculty of Economics and Business in Universitas Brawijaya explained learning through classroom teaching and discussion (active learning and cooperative learning) for subjects related to environmental accounting and reporting [39, 41, 44, 45].

Universitas Brawijaya had up to ten activities per year involving students with the main program related to environmental sustainability in 2019, namely Universitas Brawijaya's Go Green through the prohibition of the use of drinking water packaging and plastic bags and other programs such as the Fia Fun Day trash hazard campaign, Polri Caring for Greening, action clean World Clean Up Day campuses, national seminars and international conferences related to the environment, Corporate Sustainability Reporting Specialist's training, and Facing the Sea program to clean up beach waste. Universitas Brawijaya has one student organization that is still relevant in carrying out activities related to environmental sustainability, namely the Nature Lover Student Association [39, 41, 44, 45]. Universitas Brawijaya has a website that discusses environmental sustainability, namely http://greencampus.ub.ac.id/ [40]. Universitas Brawijaya does not publish sustainability reports on the university website. Universitas Brawijaya participated in the 2019 Universitas Indonesia's Green Metric assessment program organized by the Universitas Indonesia and was ranked sixteen nationally [55].

\section{Conclusion, Implication and Limitation}

Following are the conclusions obtained from the analysis of the results of the study that have been stated previously.

a. 4 out of 9 (44.44\%) Indonesia's universities included in the QS World Rankings University 2019 ranking, namely Universitas Indonesia, Universitas Padjadjaran, Institut Teknologi Sepuluh Nopember, and Universitas Brawijaya have integrated courses related to environmental accounting and reporting in the education curriculum at the undergraduate and postgraduate level in business, economic, and management faculty.

b. The Indonesia's universities included in the QS World Rankings University 2019 ranking that have integrated courses related to environmental accounting and reporting in the education curriculum at the undergraduate and postgraduate level in business, economic, and management faculty had an average of one subject in the Bachelor of Accounting and Bachelor of Economics and Development Studies at a proportion of $1.24 \%$. Courses related to environmental accounting and reporting can vary in universities namely Sustainability Reports and Environmental Audits, Integrated Sustainability and Reporting, CSR, Social Accounting, and so on.

c. 3 out of 9 (33.33\%) Indonesia's universities included in the QS World Rankings University 2019 ranking namely the Universitas Indonesia, Institut Pertanian Bogor, and Universitas Diponegoro had study programs that are still relevant to the aspects of sustainability and the environment in their educational curriculum, such as Bachelor of Economics concentrating on Resources and Environment, Bachelor of Economics and Development Studies oncentrating in Resource Economics, Bachelor of Environmental Economics and Natural Resources, Master of Environmental Economics and Natural Resources, Master of Economics concentrating on Natural Resources and Environment, Master of Tropical Marine Resources Economics, Doctor of Environmental Economics and Natural Resources, Doctor of Tropical Marine Resources Economics, and Doctor of Agricultural Economics specializing in Resource and Environmental Economics.

d. All Indonesia's universities (100\%) included in the QS World Rankings University 2019 have already had courses outside the concepts of environmental accounting and reporting 
that join other fields of economics, management, and development studies such as Project Management for Sustainable Development, Sustainable Development, Environmental Economics, Natural Resource Economics, and so on. The university which has the most subjects outside the concepts of environmental accounting and reporting that joins other sciences is Institut Pertanian Bogor with 18 courses in the Doctoral program in Resource Economics and the Environment with a proportion of $54.54 \%$. The university which has the fewest subjects outside the concepts of environmental accounting and reporting that joins other sciences is Universitas Airlangga in the Bachelor of Development Economics study program with 1 course namely Economics of Natural Resources and the Environment with a proportion of $1.49 \%$.

e. All Indonesia's universities (100\%) included in the QS World Rankings University 2019 have applied classroom teaching methods in explaining courses related to environmental accounting and reporting with different forms of learning such as discussions, case studies, and presentations.

f. All Indonesia's universities that are included in the QS World Rankings University 2019 have an average research publication that is not many numbers related to environmental accounting and reporting with an average number of publications amounted 5 studies. As many as 7 out of $9(77.78 \%)$ universities have research publications related to environmental accounting and reporting which Universitas Diponegoro has the highest portion of research publications compared to other universities. As many as 2 out of 9 (22.22\%) universities namely Universitas Padjajaran and Institut Teknologi Sepuluh Nopember do not have research publications in the internal journals of universities related to environmental accounting and reporting topics.

g. All Indonesia's universities included in the QS World Rankings University 2019 have an adequate number of activities, which are amounted minimum five activities held by universities each year involving students related to environmental sustainability. This reflects that all universities pay enough attention in supporting the initiation of universities to realize the green campus movement worldwide and help reduce social and environmental problems in society.

h. 7 out of 9 (77.78\%) Indonesia's universities included in the QS World Rankings University 2019 rank already have student organizations related to nature and the environment. There are 4 universities that have student organizations that are relevant in paying attention and reducing social and environmental problems, namely the Universitas Indonesia, Universitas Gajah Mada, Institut Pertanian Bogor, dan Institut Teknologi Sepuluh Nopember, but there are 3 other universities that only have student organizations that love nature and the activities are not specific activities in support of activities that reduce social and environmental problems namely Universitas Padjajaran, Universitas Diponegoro, dan Universitas Brawijaya.

i. 6 out of $9(66.67 \%)$ Indonesia's universities included in the QS World Rankings University 2019 have already had websites related to environmental sustainability, namely Universitas Indonesia, Universitas Gajah Mada, Institut Teknologi Bandung, Institut Pertanian Bogor, Institut Teknologi Sepuluh Nopember, dan Universitas Brawijaya. This shows that there have been efforts and commitments from universities in pursuing a green campus program which is expected to support government policy in implementing SDGs indicators.

j. Only 3 out of 9 (33.33\%) Indonesia's universities included in the QS World Rankings University 2019 have published sustainability reports on the universities' websites, namely Universitas Indonesia, Institut Pertanian Bogor, and Institut Teknologi Sepuluh Nopember. 
This finding needs to be a concern of universities since most of the universities in Indonesia express a commitment to pursuit of becoming green campus.

k. All universities in Indonesia included in the QS World Rankings University 2019's rank have participated in environmental and sustainability assessment through the 2019 University Indonesia Green Metrics. As many as 6 out of $9(66.67 \%)$ universities in Indonesia that included in the QS World Rankings University ranking 2019 has contributed to the achievement of SDGs in the world and was ranked in the top 200 Times Higher Education University Impact Rankings 2019 with the best ranking achieved by Universitas Indonesia, which was ranked 80th in the world.

1. The expected implication of this study for academics is that this research is expected to provide development for subsequent research to provide a more in-depth study of the development of the application of environmental accounting and reporting to the educational curriculum of universities in Indonesia. For universities, this study is expected to provide information and views for universities' management so that universities can analyze how many impact that can be made from application of environmental accounting and reporting in the education curriculum at the level of the study program and the integration of these on students and universities activities involving students. For the government, this study is expected to provide input for the government to determine the extent of the implementation of the green campus initiation promoted by the government both in the universities' curriculum, student activities, and university activities involving students. The limitation of this study is that this study only explains the application of environmental accounting education and in state's universities in Indonesia and does not make comparisons with the application of environmental accounting education and reporting in private universities in Indonesia or universities in other Asian countries that included in QS World University Ranking.

\section{References}

[1] Ara, Musarrat dan Harani, B. 2018. Environmental Accounting and Reporting : A Case Study of Universities' Educational Curriculum. Journal of Management, Vol. 5, No. 4, pp. 349-362.

[2] Banerjee, S. B. 2004. Teaching Sustainability: A Critical Perspective. Teaching Business Sustainability, pp. 34-47.

[3] Braun-Wanke, K. 2017. Learning and Teaching for a Sustainable Future. Handbook of Theory and Practice of Sustainable Development in Higher Education 4, pp. 15-29.

[4] Calıskan, A. O. (2014). How Accounting and Accountants May Contribute in Sustainability? Social Responsibility Journal, Vol. 10, No. 2, pp. 246-267.

[5] Das, Pradip Kumar. (2016), Environmental Accounting: A Conceptual Study of Indian Context. International Journal of Social, Behavioural, Educational, Economic, Business and Industrial Engineering, Vol. 10, No.8.

[6] Institut Pertanian Bogor. (2020). Retrieved on January 8, 2020 from https://esk.ipb.ac.id/.

[7] Institut Pertanian Bogor. (2020). Retrieved on January 8, 2020 from http://esl.fem.ipb.ac.id/.

[8] Institut Pertanian Bogor. (2020). Retrieved on January 8, 2020 from https://fem.ipb.ac.id/. 
[9] Institut Pertanian Bogor. (2020). Retrieved on January 8, 2020 from http://greencampus.ipb.ac.id/.

[10] Institut Pertanian Bogor. (2020). Retrieved on January 8, 2020 from https://ipb.ac.id/.

[11] Institut Pertanian Bogor. (2020). Retrieved on January 8, 2020 from https://journal.ipb.ac.id/index.php/jpsl/.

[12] Institut Pertanian Bogor. (2020). Retrieved on January 8, 2020 from http://pdps.pasca.ipb.ac.id/index.php/site/kurikulum.

[13] Institut Pertanian Bogor. (2020). Retrieved on January 8, 2020 from http://sb.ipb.ac.id/id/.

[14] Institut Teknologi Bandung. (2020). Retrieved on January 8, 2020 from http://www.ecocampus.itb.ac.id/.

[15] Institut Teknologi Bandung. (2020). Retrieved on January 8, 2020 from https://www.itb.ac.id/.

[16] Institut Teknologi Bandung. (2020). Retrieved on January 8, 2020 from https://www.sbm.itb.ac.id/.

[17] Institut Teknologi Sepuluh Nopember. (2020). Retrieved on January 8, 2020 from https://www.its.ac.id/id/.

[18] Institut Teknologi Sepuluh Nopember. (2020). Retrieved on January 8, 2020 from http://www.its.ac.id/iniatives/smart-eco-campus/.

[19] Januarti, I. dan D. Apriyanti. 2005. Pengaruh Tanggung Jawab Sosial Perusahaan terhadap Kinerja Keuangan. MAKSI, Vol. 5, No. 2, pp. 227-253.

[20] Kettunen, J. 2015. Stakeholder Relationships in Higher Education. Higher Education and Management, Vol. 21, No. 1, pp. 56-65.

[21] Kumparan. 2019. 7 PTN yang Masuk Daftar 'University Impact Ranking 2019'. Retrieved on March 8, 2020 from https://kumparan.com/millennial/7-ptn-yang-masukdaftar-university-impact-ranking-2019-1qqe1s9CViL/full.

[22] Kusumawardani, Anisa, et.al. (2018). Urgensi Penerapan Pendidikan Akuntansi Berbasis Akuntansi Sosial dan Lingkungan. Jurnal Ekonomi dan Keuangan, Vol. 2, No. 1, pp. 65-82.

[23] Mburayi, L. \& Wall, T. (2018). Sustainability in the Professional Accounting and Finance Curriculum: An Exploration. Higher Education, Skills and Work Based Learning.

[24] Mitali Sen, J.K. Pattanayak dan Balram Choubey. (2010). Designing a Course Curriculum on Environmental Accounting: Viewpoint of Indian industry practitioners. Social and Environmental Accountability Journal, Vol. 30, No. 2.

[25] New England Interstate Water Pollution Control Comission. 2018. Greening The Campus : Where Practice and Education Go Hand in Hand.

[26] Polejewski, S. 2011. Sustainability Accounting and Reporting. Accounting Instructor's Report 2, Summer.

[27] Richard Macve. (1997). Accounting for Environmental Cost. Working Paper in National Accounting Press. Washington D.C : National Academy Press.

[28] Sanchez, M. H. (2015). Introducing the Concepts of Sustainability and Corporate Social Responsibility to Accounting Students. Business Education and Accreditation, Vol. 7, No. 2, pp. 69-73.

[29] Santoso, H. F. (2012). Akuntansi Lingkungan Tinjauan terhadap Sistem Informasi Akuntansi Manajemen atas Biaya Lingkungan. Jurnal Akuntansi, Vol. 12, No. 2, pp. 635-654. 
[30] Tiyarattanachai, Ronnachai dan Nicholas. M. Hollmann. 2016. Green Campus Initiative and its Impacts on Quality of Life of Stakeholders in Green and Non Green Campus Universities. Springerplus.

[31] Top Universities. (2019). Retrieved on January 8, 2020 from https://www.timeshighereducation.com/university-impact-rankings-2019methodology/.

[32] Top Universities. (2019). Retrieved on January 8, 2020 from https://www.topuniversities.com/.
Universitas Airlangga. (2020). Retrieved on January 8, 2020 from http://akuntansi.feb.unair.ac.id/.

[34] Universitas Airlangga. (2020). Retrieved on January 8, 2020 from https://feb.unair.ac.id/index.php/.

[35] Universitas Airlangga. (2020). Retrieved on January 8, 2020 from https://ejournal.unair.ac.id/JDE.

[36] Universitas Airlangga. (2020). Retrieved on January 8, 2020 from https://www.unair.ac.id/.

[37] Universitas Brawijaya. (2020). Retrieved on January 8, 2020 from http://accounting.feb.ub.ac.id/.

[38] Universitas Diponegoro. (2020). Retrieved on January 8, 2020 from https://ejournal3.undip.ac.id/index.php/accounting/.
Universitas Brawijaya. (2020). Retrieved on January 8, 2020 from

[39] Universitas Brawijaya. (2020). Retrieved on January 8, 2020 from http://accounting.feb.ub.ac.id/
Universitas Brawijaya. (2020). Retrieved on January 8, 2020 from

[40] Universitas Brawijaya. (2020). Retrieved on January 8, 2020 from
http://greencampus.ub.ac.id/.

[41] Universitas Brawijaya. (2020). Retrieved on January 8, 2020 from https://ie.feb.ub.ac.id/id/.
Universitas Brawijaya. (2020). Retrieved on January 8, 2020 from

[42] Universitas Brawijaya. (2020). Retrieved on January 8,2020 from
https://ijabs.ub.ac.id/index.php/ijabs/.

[43] Universitas Brawijaya. (2020). Retrieved on January 8, 2020 from https://jamal.ub.ac.id/index.php/jamal/.

[44] Universitas Brawijaya. (2020). Retrieved on January 8, 2020 from https://selma.ub.ac.id/.

[45] Universitas Brawijaya. (2020). Retrieved on January 8, 2020 from https://ub.ac.id/id/.

[46] Universitas Diponegoro. (2020). Retrieved on January 8, 2020 from https://ejournal3.undip.ac.id/index.php/accounting/index/.

[47] Universitas Diponegoro. (2020). Retrieved on January 8, 2020 from http://iesp.feb.undip.ac.id/index.php/.

[48] Universitas Diponegoro. (2020). Retrieved on January 8, 2020 from http://www.feb.undip.ac.id/.
Universitas Diponegoro. (2020). Retrieved on January 8, 2020 from https://www.undip.ac.id/.

[50] Universitas Gajah Mada. (2020). Retrieved on January 8, 2020 from https://feb.ugm.ac.id/id/.

[51] Universitas Gajah Mada. (2020). Retrieved on January 8, 2020 from http://in.sgreeb.ft.ugm.ac.id/smart-and-green-campus/.

[52] Universitas Gajah Mada. (2020). Retrieved on January 8, 2020 from https://jurnal.ugm.ac.id/jieb/. 
[53] Universitas Gajah Mada. (2020). Retrieved on January 8, 2020 from https://mep.feb.ugm.ac.id/.

[54] Universitas Gajah Mada. (2020). Retrieved on January 8, 2020 from https://www.ugm.ac.id/.

[55] Universitas Indonesia. (2018). Petunjuk UI GreenMetric World University Rankings 2018 : Universities Impact and Sustainable Development Goals (SDGs). Depok : Universitas Indonesia

[56] Universitas Indonesia. (2019). Retrieved on January 8, 2020 from https:/www.coursehero.com/file/16052174/Silabus-LKAL-gasal14-15/.

[57] Universitas Indonesia. (2020). Retrieved on January 8, 2020 from https://aplikasi.fe.ui.ac.id/.

[58] Universitas Indonesia. (2020). Retrieved on January 8, 2020 from http://green.ui.ac.id/.

[59] Universitas Indonesia. (2020). Retrieved on January 8, 2020 from https://greenmetric.ui.ac.id/.

[60] Universitas Indonesia. (2020). Retrieved on January 8, 2020 from http://journal.ui.ac.id/tseajm/.

[61] Universitas Indonesia. (2020). Retrieved on January 8, 2020 from https://mpkp.feb.ui.ac.id/.

[62] Universitas Indonesia. (2020). Retrieved on January 8, 2020 from http://ppia.feb.ui.ac.id/.

[63] Universitas Indonesia. (2020). Retrieved on January 8, 2020 from http://ppie.feb.ui.ac.id/.

[64] Universitas Indonesia. (2020). Retrieved on January 8, 2020 from https://www.feb.ui.ac.id/

[65] Universitas Indonesia. (2020). Retrieved on January 8, 2020 from http://www.sci.ui.ac.id/.

[66] Universitas Indonesia. (2020). Retrieved on January 8, 2020 from https://www.ui.ac.id/.

[67] Universitas Padjajaran. (2020). Retrieved on January 8, 2020 from http://www.feb.unpad.ac.id/.

[68] Universitas Padjajaran. (2020). Retrieved on January 8, 2020 from http://www.unpad.ac.id/.

[69] United States Environmental Protection Agency. (2015). Sustainability. http://www.epa.gov/sustainability/basicinfo.html.

[70] United Nations. (1987). Our Common Future. Brundtland Report: Oxford University Press, pp. 204.

[71] U.S Environmental Protection Agency. (2015). Sustainability and The U.S. EPA. Washington, D.C.: The National Academic Press.

[72] Wesustain Western Michigan University. (2018). Spring 2018 Student Sustainability Survey and Literacy Assesment - Raw Result Compilation.

[73] Wymer, W. dan S. R. Rundle-Thiele. 2017. Inclusion of Ethics, Social Responsibility, and Sustainability in Business School Curricula: A Benchmark Study. International Review on Public and Nonprofit Marketing, Vol. 14, No. 1, pp. 19-34. 